\title{
DOES CROSSBREEDING BETWEEN EGYPTIAN AND ITALIAN BUFFALOES AFFECT PRODUCTIVE AND REPRODUCTIVE PERFORMANCE?
}

\author{
M.A.F. Nasr \\ Animal Wealth Development Department, Faculty of Veterinary Medicine, Zagazig University, Egypt. \\ Correspondence: E-mail: Mohammed.nasr@zu.edu.eg $\quad$ Nasr.maf@gmail.com
}

Received: 29/8/2019 Accepted: 15/10/2019

\section{SUMMARY}

Buffaloes rank universally as the second precious species for milk production. In the last few decades the worldwide total number of buffaloes has increased from 184 to 201 million heads. Despite of the recent reduction (17.76\%) of buffalo's population, Egypt still holding the fifth position for the world regarding buffalo numbers. Italian buffaloes produce high milk yield $(2,250 \mathrm{~kg} /$ lactation) and butter fat (8\%), compared to Egyptian buffalo (1850 kg milk/lactation) in conventional herds and $1960 \mathrm{~kg}$ milk/lactation in modern dairy herds. Improving buffalo performance is a significant issue that should be achieved via genetic selection, crossbreeding and good management. First cross $\left(F_{1}\right)$ between Egyptian and Italian buffaloes (50\% Egyptian and 50\% Italian) and backcross (BC) (75\% Egyptian and 25\% Italian) produced higher milk yield than pure Egyptian buffaloes (PE) and BC was the best compared to $F_{1}$ and PE (2511.59kg of milk/lactation). Also, BC showed signs of robustness at the different temperature-humidity index (THI) levels similar to PE. They had the lowest non-conceived percentage after first insemination, with the best rate of delivering live calves and easy calving at various categories of THI. BC buffaloes are more tolerant to the challenging Egyptian environmental conditions. This may be attributable to that BC buffaloes have a higher percentage of the Egyptian blood and consequently are more adaptable to the Egyptian environment.

Keywords: Egyptian buffalo, Italian buffalo, crossing, productive and reproductive performance

\section{INTRODUCTION}

\section{Buffaloes:}

Domestic water buffalo (Bubalus bubalis) is classified into river and swamp buffaloes. The river buffalo is chiefly present in India, the Mediterranean, Caribbean countries and Africa, while the swamp buffaloes are restricted to Asia principally China, India, Philippines, Vietnam, and Bangladesh (Kumar et al., 2007). The river buffaloes are preferred to be used for milk production than for meat or draft (Nam, 2010). In the last few decades the worldwide total number of buffaloes has increased from 184 to 201 million heads (FAOSTAT, 2019). Despite of the recent reduction in buffalo population, Egypt still holding the fifth position of buffalo numbers after India, Pakistan, China and Nebal. Dairying in Egypt represents an imperative role stands for approximately $47 \%$ of food supply from agriculture enterprises (RAC/CP, 2002). The average of milk consumption in Egypt is around $61.8 \mathrm{~kg} /$ capita/year (FAOSTAT, 2015), comprising the raw milk and products, like butter, cheese and yogurt (LACTIMED, 2014), but, still lesser than the mean world consumption (100 kg/capita/year).

Buffaloes rank universally as the second precious species for milk production (Han et al., 2012; Coroian et al., 2013) that yield high-quality milk with relatively high fat, protein, lactose, mineral content, but affords only $13 \%$ of the total world milk consumption due to small animal population relatively low milk yield (Liu et al., 2017). Nevertheless, buffaloes produced low milk quantity when compared to the dairy cows. However, buffalo milk price is roughly three times that of lactating cows (Rosati and Van Vleck, 2002). Buffalo milk presents the first choice in several countries as it is greatly prized owing to its pure white color, rich fat and satisfactory flavor (Abd El-Salam and ElShibiny, 2011). Further advantage, buffaloes are more capable of transferring low-quality forages with low digestible features to milk or meat when compared to cows (Ibrahim, 2012). Socioeconomically, water buffalo is deemed a most critical species in developing countries, like Egypt, which develops the life aspects of farmers (Aggarwal and Upadhyay, 2013).

The concurrent temperature weather temperature, relative humidity, solar radiation and heat stress in tropical and subtropical countries form imperative restrictions on animal performance (Marai et al., 2009). The summer temperature in Egypt is depicted as moderate to high with moderate humidity levels. Dairy animals could be drastically influenced by heat stress as a result of harsh hot and humid climate as of Egypt, which consequently, influence the welfare, health, survival, reproduction and production of these animals (Dunn et al., 2014). However, buffaloes have extraordinary ability to endure the adverse environmental circumstances with a distinguished longevity (approximately ten years; Dunn et al., 2013). Egyptian buffaloes resist diseases and adapt to 
the restricted environmental circumstances. They exceed cows aptitude to adapt in hot and humid conditions of muddy and swampy lands (Vale, 2007), and still perform well in very hot weathers of tropics and subtropics (Marai and Habeeb, 2010). The adaptability factor is much higher for buffalo than for Friesian cow (Marai et al., 2009).

Italian buffaloes are possibly the exclusive to have massive availability of databases regarding genetic structure, applied knowledge, inspection of pathologies, hygiene and products quality (Allam et al., 2015). They produce the highest milk yield $(2,250 \mathrm{~kg} /$ lactation $)$ and fat \% $(8 \%)$ in the world (Varricchio et al., 2007; Allam et al., 2015). In Egypt, buffaloes produce an average of $1850 \mathrm{~kg}$ milk/lactation period $(6.3 \mathrm{~kg} /$ day $)$ in conventional herds and $1960 \mathrm{~kg}$ milk/lactation $(7.1 \mathrm{~kg} /$ day) in modern dairy herds (Borghese, 2010; Ibrahim, 2012).

\section{Improving buffalo performance:}

During the coming two decades, the world population of buffaloes is expected to be notably enlarged due to the growing demand for high-quality dairy products with attractive and competent characters (Castellano et al., 2019). This augments the necessity for research, intending to multiply milk precious elements to devoid shifting in manufacturing eminence. Therefore, an imperative need for applying a better and more proficient production development is necessary. Escalating milk production is the principal rational of selection in dairy farms; accordingly, the foremost aim in buffalo breeding is to intensify their future production performance (Nasr et al., 2016). The procedure of improving buffalo breeds is enormously convoluted, as selection for a single trait possibly will consequence a negative effect on milk quality in addition to the reproduction (Barros et al., 2014). Egypt undergoes a massive production gap in milk and meat production as observed in their annual importation. Buffalo couldn't plug this gap as a result of the lack of specialized breeds for meat $/ \mathrm{milk}$ production. Therefore, there is a necessity for adopting national genetic upgrading programs.

Enhancing buffalo performance is crucial and ought to be done via selection and genetic development (Fooda et al., 2011a). The moderate heritability of milk production, revealed that it will respond to direct mass selection (Malhado et al., 2013). Due to this, little exchange of breeding buffaloes among countries, resident populations have distinct phenotypic characteristics and performances (Khan, et al., 2011). Crossing Swamp and River buffaloes seems to be a prospective vital approach to achieve genetic improvement (El-Shamaa et al., 1997), due to introducing genes of high milk yield into the Swamp buffalo to be used as a triple-purpose animal to produce milk in addition to meat and work. Artificial insemination is a feasible technique to aid plans for upgrading buffalos' performances. Genetic upgrading via crossbreeding and selection should be applied together with good management to enhance the animal performance.

Although Egypt possesses large number of buffaloes compared to Italy, but production/head is much lower. Italy has spent massive efforts in constructing, designing selection and breeding plans and developing feeding strategies (Borghese, 2010). The current research is an endeavour to adopt similar steps to cross the pure Egyptian buffaloes (PE) with the exotic Italian or Pakistani buffaloes, with a general objective aiming at enhancing the production performance and reproductive efficiency of Egyptian buffaloes. In 1980, the Animal Production Research Institute (APRI) imported Pakistani buffalo semen for the purpose of increasing milk yield of local buffaloes. In 2003, Ministry of Agriculture permitted the commercial introduction of Italian buffalo semen that was arbitrarily utilized on large scale in buffalo farms. The introduction of these foreign buffalo breeds was performed with an intention to improve the genetic structure of the Egyptian buffaloes for the economic traits, as was done with the indigenous dairy breeds.

\section{Impact of crossing on buffalo production:}

There have been conflicting arguments concerning the impact of crossing PE with Italian buffaloes. Some researchers perceived no difference in the performance of the Egyptian buffaloes due to crossing science their performance was comparable to that of other breeds, and claimed that the introduction of foreign buffalo breeds will not play a significant role in changing the genetic makeup of the Egyptian buffaloes as was in case of the native cows. Others have reported that crossing with Italian buffaloes would improve the performance of Egyptian buffalo breeds (Fooda et al., 2011a; Allam et al., 2015; Nasr, 2016a, 2017a,b). Allam et al. (2015) compared the milk yield of Egyptian buffaloes and Egyptian-Italian crosses and detected minor increase in milk yield due to crossing. Crossbred buffaloes had 24 days longer lactation period, with 5-6 liters more daily milk yield (during the whole lactation period) compared to Egyptian buffaloes. The fat, SNF and protein percents were $3.75,1.5$ and $0.47 \%$, respectively higher, but SCC were lesser in crosses than that of Egyptian buffaloes. Moreover, the Egyptian buffaloes revealed 14.29\% mastitic cases/lactation period and $4.29 \%$ were diagnosed with diarrhea, compared to $2.86 \%$ mastitic and absence of diarrhea in Egyptian- Italian crosses.

Crossing Egyptian with Pakistani buffaloes revealed an increase in milk yield compared to the pure Egyptian buffalo which exhibiting positive impact of crossbreeding with Pakistani buffaloes on milk production. Nasr (2016b) compared the milk production of first cross $\left(\mathrm{F}_{1}, 50 \%\right.$ Egyptian and $50 \%$ Italian) and back cross (BC, 75\% Egyptian and 25\% Italian) with the pure Egyptian buffaloes (PE) and reported that $\mathrm{F}_{1}$ and $\mathrm{BC}$ producing high average daily milk yield than PE $(9.57,9.84$ and $8.03 \mathrm{~kg}$, 
respectively) and has also, similar trend for peak milk yield $(15.31,14.03$ and $12.99 \mathrm{~kg}$, respectively), due to the positive correlation between the two traits (Phathodiya et al., 1999). All peak yields (8-12kg) were higher than those reported by Thiruvenkadan et al. (2014) probably due to the different genetic background and the better feed quality (Hamid et al., 2003). Furthermore BC produced $2511 \cdot 59 \mathrm{~kg}$ of milk/lactation that was 103 and $235 \mathrm{~kg}$ higher than $\mathrm{F}_{1}$ and $\mathrm{PE}$ production and also 0.87 and $1.05 \mathrm{~kg}$ of milk/day higher than $F_{1}$ and $P E$ daily yield, respectively (Nasr, 2016a). Increasing the percentage of Egyptian blood as in BC group increased the adaptability coefficient to the local environment (Fooda, et al., 2011a). Moreover, BC showed signs of robustness at the different THI levels, similar to PE (Nasr, 2016a). They could endure the rough circumstance and become more accustomed to the hot Egyptian weather due to the higher percentage of Egyptian blood in BC (Fooda, et al., 2011a).

\section{Impact of crossing on buffalo reproduction:}

Reproductive performance has an immense influence on the profitability of the dairy animal production (Berry and Cromie, 2009). There have been incompatible outputs concerning the effects of crossing between pure Egyptian and Italian buffaloes on reproduction. Some researchers perceived no evidence of affection on reproduction and others have reported that crossing with Italian buffaloes improved the reproductive performance of Egyptian buffalo breeds (Nasr, 2016a,b, 2017a,b; Allam et al., 2015). Calving interval, service period and days open were longer in $\mathrm{F}_{1}$ (Egyptian $\times$ Italian crossbred) buffaloes than those of PE with age at first calving being 28 and 32 months, respectively and reproductive performance of PE surpassing $\mathrm{F}_{1}$ (Fooda et al., 2011b; Allam et al., 2015).

Calving interval is one of the fundamental reproductive parameters, which govern the herd reproductive performance as the shorter the interval, the larger the number of lifetime progeny delivered for each female buffalo (Ramos et al., 2006). Calving interval of $\mathrm{PE}$ was between 395-418 days (Fooda et al., 2011b; Nasr, 2017a), while for $\mathrm{F}_{1}$ and BC were shorter than that for pure Italian buffaloes (Partha, 1970). The average number of services per conception was 1.9 for PE (Damarany et al., 2013), but improved recently by crossing. Back-crossed buffaloes had the lowest non-conceived percentage following first insemination ( $\mathrm{OR}=0.74$ with $95 \%$ confidence interval [0.66-0.83]) (Nasr, 2016b). BC had the best conceived rate post the first insemination at various THI categories (low $72.20 \%$, medium $72.60 \%$, and high $62.40 \%$ ) than that for PE which was $63.50 \%, 69.30 \%$ and $59.40 \%$, respectively. Also, $\mathrm{BC}$ group had the highest rate of live calves delivery (98.50, 100 and $99.40 \%$ ) and of easy calving (98.50, 100 and $99.40 \%$ ) as compared to $\mathrm{PE}$ and $\mathrm{F}_{1}$ at various levels of THI, respectively (Nasr 2017b).

For a dairy enterprise to be successful, restricted better management regime to guarantee calf survival must be followed. Stillbirth in buffaloes is a major recurring reproductive problem that represents virtually $42.3 \%$ of the whole reproduction disorders (Ilieva and Peeva, 2008), but may vary from herd to herd. It was $0.09 \%$ in rural environment (Prasad and Prasad, 1998), while was 0.67 to $9.2 \%$ in farms (Parekh and Singh, 1981) and it was up to $34 \%$ for Pakistan buffalo (Hashmi et al., 2013) and $13.90 \%$ in Egypt (Nasr, 2016b). Economic losses caused by stillbirth cases incorporate calves death (Maizon et al., 2004), dam mortality, reduced survivability and premature culling which elevates the cost of veterinary assistances (Szücs et al., 2009). Crossing however, may form a solution to overcome some of the above mentioned issues. Crossing between PE and Italian buffalo $\left(\mathrm{F}_{1}\right.$ and $\left.\mathrm{BC}\right)$ had lower rate of calving difficulty $(\mathrm{OR}=0.34 \quad[0.25-0.47] \quad$ and $\mathrm{OR}=0.18[0.14-0.24]$, respectively) with smaller rate of stillbirth $(\mathrm{OR}=0.43[0.35-0.54]$ and $\mathrm{OR}=0.06$ [0.04-0.10], respectively) when compared with $\mathrm{PE}$ (Nasr, 2016b). In addition, $B C$ and $F_{1}$ had a lower rate of stillbirth at $2^{\text {nd }}-4^{\text {th }}$ and $5^{\text {th }}-7^{\text {th }}$ parities than that of PE (Nasr, 2017a). Surprisingly, PE has the highest stillbirth odds ratio (Nasr, 2016b). The general causes of variation may be due to the anatomical dissimilarities of pelvis size, ileum area (Kodagali, 2003), vaginal canal and vulvar lips width (Agarwal and Tomer, 1998), moreover to that PE revealed the heaviest calf weight $(40.48 \mathrm{~kg})$ when compared with $\mathrm{F}_{1}$ and $\mathrm{BC}$ (39.86 and $39.87 \mathrm{~kg}$, respectively) (Nasr, 2016b).

\section{CONCLUSION}

In conclusion backcross towards $\mathrm{PE}$ was comparable to $\mathrm{F}_{1}$ for production and to $\mathrm{PE}$ for reproduction performance. Moreover, it revealed the lowest incidence of calving difficulty and stillbirth in concurrence with the best conception incidence after first insemination. Therefore, $\mathrm{BC}$ can withstand the challenging environmental conditions in Egypt and stillbirth without deterioration in production and reproduction performance compared to $\mathrm{PE}$.

\section{REFERENCES}

Abd El-Salam, M.H.A. and S.A. El-Shibiny, 2011. A comprehensive review on the composition and properties of buffalo milk. Dairy Sci. Technol., 91: 663.

Agarwal, S.K. and O.S. Tomer, 1998. Reproductive technologies in the buffalo. Izatnagar, India: Indian Veterinary Research Institute Karnal India; 1998.

Aggarwal, A. and R. Upadhyay, 2013. Heat stress and milk production. In Heat Stress and Animal Productivity, (Ed. Aggarwal A \& Upadhyay R), pp. 53-77. New Delhi: Springer.

Allam, H.A., M.B. Mahmoud and A. Fathi, 2015. A study for comparison between immune status of dairy Egyptain buffaloes and the crosses of 
Egyptain-Italian buffaloes under the Egyptian environment. Am. J. Sci., 11(1): 53-56.

Barros, C.C., D.P. Oliveira, N.A. Hurtado-Lugo, R. Aspilcueta-Borquis and H. Tonhati, 2014. Estimates of genetic parameters for economic traits in dairy buffalo. In Proceedings, 10th World Congress of Genetics Applied to Livestock Production, 17-22 August 2014, Vancouver, BC, Canada, Poster 804

Berry, D. and A. Cromie, 2009. Associations between age at first calving and subsequent performance in Irish spring calving HolsteinFriesian dairy cows. Livestock Sci., 123: 44-54.

Borghese, A., 2010. Development and perspective of buffalo and buffalo market in Europe and Near East. In Proc. 9th World Buffalo Congress, Buenos Aires, 25-28 pp.

Castellano, L.E.H., J.E. Nally, J. Lindahl, M. Wanapat, I.A. Alhidary, D. Fangueiro, D. Grace, M. Ratto, J.C. Bambou and A.M. de Almeida, 2019. Dairy science and health in the tropics: challenges and opportunities for the next decades. Trop. Anim. Health Prod., 51: 1009-1017.

Coroian, A., S. Erler, C.T. Matea, V. Miresan, C. Raducu, C. Bele and C.O. Coroian, 2013. Seasonal changes of buffalo colostrum: physicochemical parameters, fatty acids and cholesterol variation. Chem. Cent. J., 7: 2-9.

Damarany, A.I., M.A.E. Ali and R.M. Ammar, 2013. Reproductive characteristics of the baladi cows and Buffaloes under traditional management conditions in Upper Egypt. Proceedings of the 4th scientific conference of Animal Production Research Institute, 12-13 November 2013, Dokki, Giza, Egypt, 442-449.

Dunn, D., C.H.O. Lallo, D. Carnadovan and G. Ram, 2013. The performance and heat tolerance of water buffaloes (Buffalypso) at Aripo Livestock Station, Trinidad. Tropical Agriculture (Trinidad), 90: 97-108.

Dunn, R.J.H., N.E. Mead, K.M. Willett and D.E. Parker, 2014. Analysis of heat stress in UK dairy cattle and impact on milk yields. Environ. Res. Lett., 9: 1-11.

El-Shamaa, I.S., R.M. Khattab, M.A. Ibrahim and S.A. Darwish, 1997. Testicular changes associated with onset of puberty in relation to season of birth in Egyptian buffalo males. Annals of Agric., 50, Moshtohor, 35(1): 227-241.

FAOSTAT, 2019. Food and Agriculture Organization of the United Nations. http://www.fao.org/faostat/en/\#data/QL/visualize

FAOSTAT, 2015. Food and Agriculture Organization of the United Nations. http://faostat3.fao.org/browse/Q/QA/E.

Fooda, T.A., A.R. Elbeltagi, L.R. Hassan and S.S. Awad, 2011a. Assessment of Egyptian buffaloes crossing with Pakistani and Italian buffaloes for some production traits. Am. J. Sci., 7(1).

Fooda, T.A., A.R. Elbeltagi, L.R. Hassan and S.S. Awad, 2011b. Evaluated of Egyptian buffaloes crossing with Italian buffaloes for reproductive traits. Am. J. Sci., 7: 209-213.

Hamid, S.K., M. Farooq, M.A. Mian, M. Syed and S. Jamal, 2003. Milk production performance and inter-relationship among traits of economic importance in buffaloes maintained at commercial dairy farms. Livestock Res. Rural Dev., 15: 3045.

Han, X., F.L. Lee, L. Zhang and M.R. Guo, 2012. Chemical composition of water buffalo milk and its low-fat symbiotic yogurt development. Functional Foods in Health and Disease, 2: 86106.

Hashmi, H.A., T.M. Tarique, S. Yang, M. Zubair, J. Qiu, G. Chen and A. Chen, 2013. Factors affecting mortality in buffaloes and calves. International Journal of Agricultural Sciences and Veterinary Medicine, 1: 1-6.

Ibrahim, M.A.M., 2012. Effect of enrollment in milk recording systems on improving milk production of Egyptian buffalo. J. Animal and Poultry Prod., Mansoura Univ., 3(1): 39-46.

Ilieva, J.O. and T.S. Peeva, 2008. Influence of reproductive disorders on some productive traits in buffalo cows. Zhivotnov'Dni Nauki, 3: 29-34.

Khan, G., S.K. Church, R. Harding, P. Lunde, J. McIntosh and C. Stone, 2011. The first civilizations in contact: Mesopotamia and the Indus. The Civilizations in Contact Project, Faculty of Asian and Middle Eastern Studies, University of Cambridge.

Kodagali, S.B., 2003. Notes on applied bovine reproduction. Part II. In: Kodagali SB. Bovine Obstetrics. Anand, Gujarat, India: Indian Society for Study of Animal Reproduction.

Kumar, S., M. Nagarajan, J.S. Sandhu, N. Kumar, V. Behl and G. Nishanth, 2007. Mitochondrial DNA analyses of Indian water buffalo support a distinct genetic origin of river and swamp buffalo. Anim. Genet., 38: 227-232.

LACTIMED, 2014. Developing the typical dairy products of Alexandria and Beheira: Diagnosis and local strategy. 54 p. www.lactimed.eu.

Liu, J.J., A.X. Liang, G. Campanile, G. Plastow, C. Zhang, Z. Wang, A. Salzano, B. Gasparrini, M. Cassandro and L.G. Yang, 2017. Genome-wide association studies to identify quantitative trait loci affecting milk production traits in water buffalo. J. Dairy Sci., 101: 433-444.

Maizon, D.O., P.A. Oltenacu, Y.T. Grohn, R.L. Strawderman and U. Emanuelson, 2004. Effects of diseases on reproductive performance in Swedish Red and White dairy cattle. Prev. Vet. Med., 66: 113-126.

Malhado, C.H.M., A.C.M. Malhado, A.D.A. Ramos, P.L.S. Carneiro, J.C.D. Souza and A. Pala, 2013. Genetic parameters for milk yield, lactation length and calving intervals of Murrah buffaloes from Brazil. Revista Brasileira de Zootecnia, 42: 565-569. 
Marai, I.F.M. and A.A.M. Habeeb, 2010. Buffaloes' reproductive and productive traits as affected by heat stress. Tropical and Subtropical Agroecosystems, 12: 193-217.

Marai, I.F.M., A.H. Daader, A.M. Soliman and S.M.S. El-Menshawy, 2009. Non genetic factors affecting growth and reproduction traits of buffaloes under dry management housing (in subtropical environment) in Egypt. Livestock Res. Rural Dev., 21: 1-13.

Nam, N.H., 2010. Characteristics of reproduction of the water buffalo and techniques used to improve their reproductive performance. J. Sci. Dev., $8: 100-110$.

Nasr, M.A.F., 2016a. The impact of crossbreeding Egyptian and Italian buffalo on milk yield and composition under subtropical environmental conditions. J. Dairy Res., 83: 196-201.

Nasr, M.A.F., 2016b. The impact of crossbreeding Egyptian and Italian buffalo on reproductive and productive performance under subtropical environmental condition. Reprod. Dom. Anim., 52(2): 214-220.

Nasr, M.A.F., A. Awad and I.E. Araby, 2016. Associations between Leptin and Pituitaryspecific transcription factor genes polymorphisms and reproduction and production traits in dairy buffalo. Reprod. Dom. Anim., 51: 597- 603.

Nasr, M.A.F., 2017a. The effect of stillbirth on reproductive and productive performance of pure Egyptian buffaloes and their crosses with Italian buffaloes. Theriogenology, 103: 9-16.

Nasr, M.A.F., 2017b. The potential effect of Temperature-Humidity Index on productive and reproductive performance of buffaloes with different genotypes under hot conditions. Environ. Sci. Pollut. R., 24(22):18073-18082.

Parekh, H.K.B. and A. Singh, 1981. Mortality pattern in crossbred of Gir with Friesian and Jersey sires. Indian J. Dairy Sci., 51(4): 419-424.
Partha, N.R., 1970. Service period, calving interval and dry period in Italian buffaloes. Zentralblatt für Veterinärmedizin Reihe A, 17: 284-286.

Phathodiya, O.P., L.S. Jain and S.P. Tailor, 1999. Age at first calving and its correlation with economic traits in Surti buffalo. Indian Veterinary Journal, 76: 902-905.

Prasad, S. and R.B. Prasad, 1998. Measures of reproductive estimates in rural buffalo herds of Meerut district of Uttar Pradesh (India). Buffalo Bulletin, 17: 27-29.

RAC/CP., 2002. Prevention of pollution in the dairy industry regional activity centre for cleaner production. Mediterranean Action Plan Web page: http://www.cema-sa.org.

Ramos, A.A., C.H.M. Malhado and P.L.S. Carneiro, 2006. Caracterizaçao fenotipica e genetica da produçao de leite e do intervalo entre partos em bubalinos da Raça Murrah. Pesquisa Agropecuaria Brasileira, 41: 1261-1267.

Rosati, A. and L.D. Van Vleck, 2002. Estimation of genetic parameters for milk, fat, protein and mozzarella cheese production for the Italian river buffalo Bubalus bubalis population. Livest. Prod. Sci., 74: 185-190.

Szücs, E., L. Gulyás, L.T. Cziszter and I. Demirkan, 2009. Stillbirth in dairy cattle: Review. Lucrări ştiinţifice Zootehnie şi Biotehnologii, 42(2): 622636.

Thiruvenkadan, A.K., S. Panneerselvam, N. Murali, S. Selvam and V.R. Saravanakumar, 2014. Milk production and reproduction performance of Murrah buffaloes of Tamil Nadu, India. Buffalo Bulletin, 33: 291-300.

Vale, W.G., 2007. Effects of environment on buffalo reproduction. Ital. J. Anim. Sci., 6(Suppl. 2): 130-142.

Varricchio, M.L., A. Di Francia, F. Masucci, R. Romano and V. Proto, 2007. Fatty acid composition of Mediterranean buffalo milk fat. Ital. J. Anim. Sci., 6: 509-511. 